In cooperation with the Lake County Forest Preserve District

\title{
Sediment Coring and Sedimentation Analysis on Rasmussen Lake in Ethel's Woods Forest Preserve near Old Mill Creek, Illinois in 2005
}

Scientific Investigations Report 2006-5158 


\section{Sediment Coring and Sedimentation Analysis on Rasmussen Lake in Ethel's Woods Forest Preserve near Old Mill Creek, Illinois in 2005}

By Timothy D. Straub, Donald P. Roseboom, and Phillip G. Dennis

In cooperation with the Lake County Forest Preserve District

Scientific Investigations Report 2006-5158 


\section{U.S. Department of the Interior DIRK KEMPTHORNE, Secretary \\ U.S. Geological Survey \\ P. Patrick Leahy, Acting Director}

\section{U.S. Geological Survey, Reston, Virginia: 2006}

For product and ordering information:

World Wide Web: http://www.usgs.gov/pubprod

Telephone: 1-888-ASK-USGS

For more information on the USGS--the Federal source for science about the Earth, its natural and living resources, natural hazards, and the environment:

World Wide Web: http://www.usgs.gov

Telephone: 1-888-ASK-USGS

Any use of trade, product, or firm names is for descriptive purposes only and does not imply endorsement by the U.S. Government.

Although this report is in the public domain, permission must be secured from the individual copyright owners to reproduce any copyrighted materials contained within this report.

Suggested citation:

Straub, T.D., Roseboom, D.P., and Dennis, P.G., 2006, Sediment coring and sedimentation analysis on Rasmussen Lake in Ethel's Woods Forest Preserve near Old Mill Creek, Illinois in 2005: U.S. Geological Survey Scientific Investigations Report 2006-5158, $13 p$. 


\section{Contents}

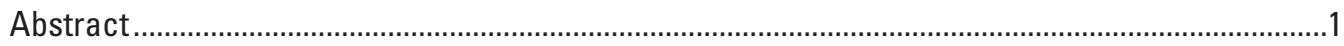

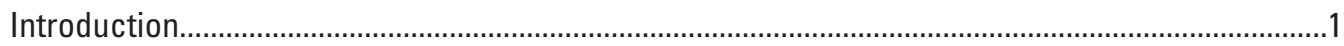

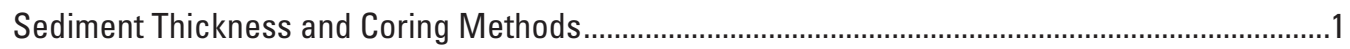

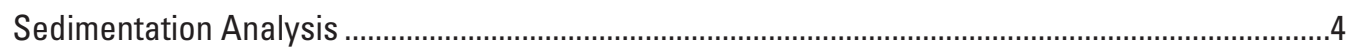

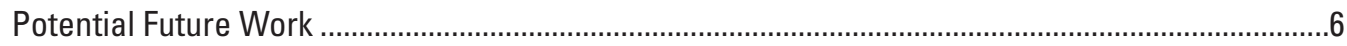

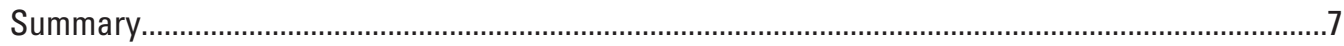

Acknowledgments

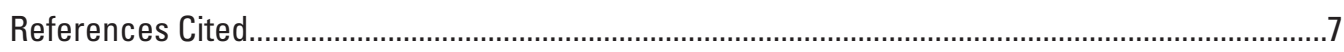

Appendix A: Sample Locations on Rasmussen Lake in Ethel's Woods Forest Preserve near

Old Mill Creek, Illinois ..........................................................................................................

Appendix B: Sediment Summary for Transects on Rasmussen Lake in Ethel's Woods Forest

Preserve near Old Mill Creek, Illinois ................................................................................10

\section{Figures}

1. Map showing location of Rasmussen Lake in Ethel's Woods Forest Preserve, near Old Mill

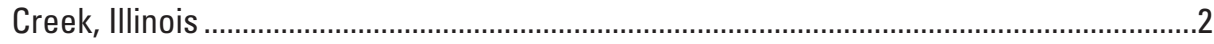

2. Map showing sediment thicknesses and coring locations on Rasmussen Lake in Ethel's

Woods Forest Preserve, near Old Mill Creek, Illinois ...........................................................3

3. Photograph showing lake sediment core in a clear plastic liner tube ..........................................

4. Graph showing maximum and average sediment thicknesses for each transect on Rasmussen

Lake in Ethel's Woods Forest Preserve, near Old Mill Creek, Illinois..................................5

5. Diagram of a nickpoint, and example of nickpoint progression after gradual removal of

Brewster Creek dam near St. Charles, Illinois ....................................................................6

\section{Table}

1. Surface area, average-transect sediment thickness, and sediment volumes of

Rasmussen Lake in Ethel's Woods Forest Preserve, near Old Mill Creek, Illinois.............4 


\section{Conversion Factors and Horizontal Datum}

\begin{tabular}{lcl}
\hline \multicolumn{1}{c}{ Multiply } & By & \multicolumn{1}{c}{ To obtain } \\
\hline inch (in.) & Length & \\
foot (ft) & 25.4 & millimeter $(\mathrm{mm})$ \\
\hline & 0.3048 & meter $(\mathrm{m})$ \\
\hline acre & Area & \\
square foot $\left(\mathrm{ft}^{2}\right)$ & 4,047 & square meter $\left(\mathrm{m}^{2}\right)$ \\
section $(640$ acres or 1 square mile) & 0.09290 & square meter $\left(\mathrm{m}^{2}\right)$ \\
\hline & 259.0 & square hectometer $\left(\mathrm{hm}^{2}\right)$ \\
\hline acre-foot (acre-ft) & Volume & \\
\hline
\end{tabular}

Horizontal coordinate information is referenced to the World Geodetic System 1984 (WGS 84). 


\title{
Sediment Coring and Sedimentation Analysis on Rasmussen Lake in Ethel's Woods Forest Preserve near Old Mill Creek, Illinois in 2005
}

\author{
By Timothy D. Straub, Donald P. Roseboom, and Phillip G. Dennis
}

\begin{abstract}
The Lake County Forest Preserve District (LCFPD) is investigating the possibility of modifying the dam on Rasmussen Lake in Ethel's Woods Forest Preserve. The lake is of low water quality with an eroding shoreline. Sediments have been deposited in the impoundment over the last 50 years. Twenty-eight sediment sampling locations were identified along seven transects over a 51.4 acre area in Rasmussen Lake to determine sediment thickness and obtain sediment material for physical and chemical analyses. The maximum sediment thickness was consistently 3.0-4.5 feet (ft) from the dam to the upper end of the lake. The sediment thickness was less than $2.5 \mathrm{ft}$ near the shore and in transect 5, near the northern part of the lake. Sediment thickness did not increase either in the upstream or downstream direction. The average-transect sediment thicknesses ranged from $1.8 \mathrm{ft}$ to $2.7 \mathrm{ft}$. The approximate total sediment volume that has accumulated in the 51.4 acres of the lake over the past 50 years is 115.1 acre-feet.
\end{abstract}

\section{Introduction}

Rasmussen Lake is in the Ethel's Woods Forest Preserve, near Old Mill Creek, Illinois. The Preserve is 475.5 acres, and the land was purchased by the Lake County Forest Preserve in 2001 (Lake County Forest Preserve, 2006). Rasmussen Lake covers approximately 55 acres within the Preserve and was created by a dam constructed on North Mill Creek in the late 1950's (fig. 1). There is a U.S. Geological Survey (USGS) streamflow gaging station (station number 05527950) downstream from the lake on Mill Creek (fig. 1).

Rasmussen Lake is of low water quality with an eroding shoreline (Colwell and others, 2002). Sediments have settled in the impoundment over the last 50 years. The Lake County Forest Preserve District (LCFPD) is investigating the possibility of modifying the dam to release the impoundment and restore the lake to its original riparian condition. LCFPD needed to collect and analyze exploratory lake-bottom core samples at 28 specified locations within Rasmussen Lake as part of the determination of dam modification feasibility. In 2005, the U.S. Geological Survey, Illinois Water Science Center (USGS-IWSC) and the LCFPD began a cooperative study to collect sediment cores and investigate sedimentation in Rasmussen Lake.

This sedimentation analysis will be helpful to waterresource managers in selection of dam modification strategies throughout northeastern Illinois. The methods and analyses used in this study can potentially be applied to similar watersheds in the Midwest with older impoundments. Rasmussen Lake is similar to other impoundments in the Midwest and the data and analysis may be of benefit to regional and national studies by furthering the knowledge of sedimentation in impounded waters. Results of this study can be used in conjunction with a possible future study of the dewatered sediments and monitoring of the sediment entering and exiting the lake before, during, and after lowering the dam.

The purpose of this report is to outline the methods for obtaining sediment thickness and cores, and corresponding preliminary sedimentation analysis in Rasmussen Lake. Sediment cores were collected for physical and chemical analyses. The physical analyses are discussed in this report, but chemical analyses are not included.

\section{Sediment Thickness and Coring Methods}

Twenty-eight sediment sampling locations were identified along seven transects in Rasmussen Lake (fig. 2 and appen$\operatorname{dix}$ A) to determine sediment thickness and obtain sediment material for physical and chemical analyses. Four sampling locations were selected at equal intervals along each of seven transects. Monument points were established by driving fence posts at each end of the seven transects. The black dots in figure 2 indicate the edge of water and the monument points.

A tag line was stretched between the monument points on opposite banks of the lake. The location of the bank monuments and sampling locations were documented as distance 


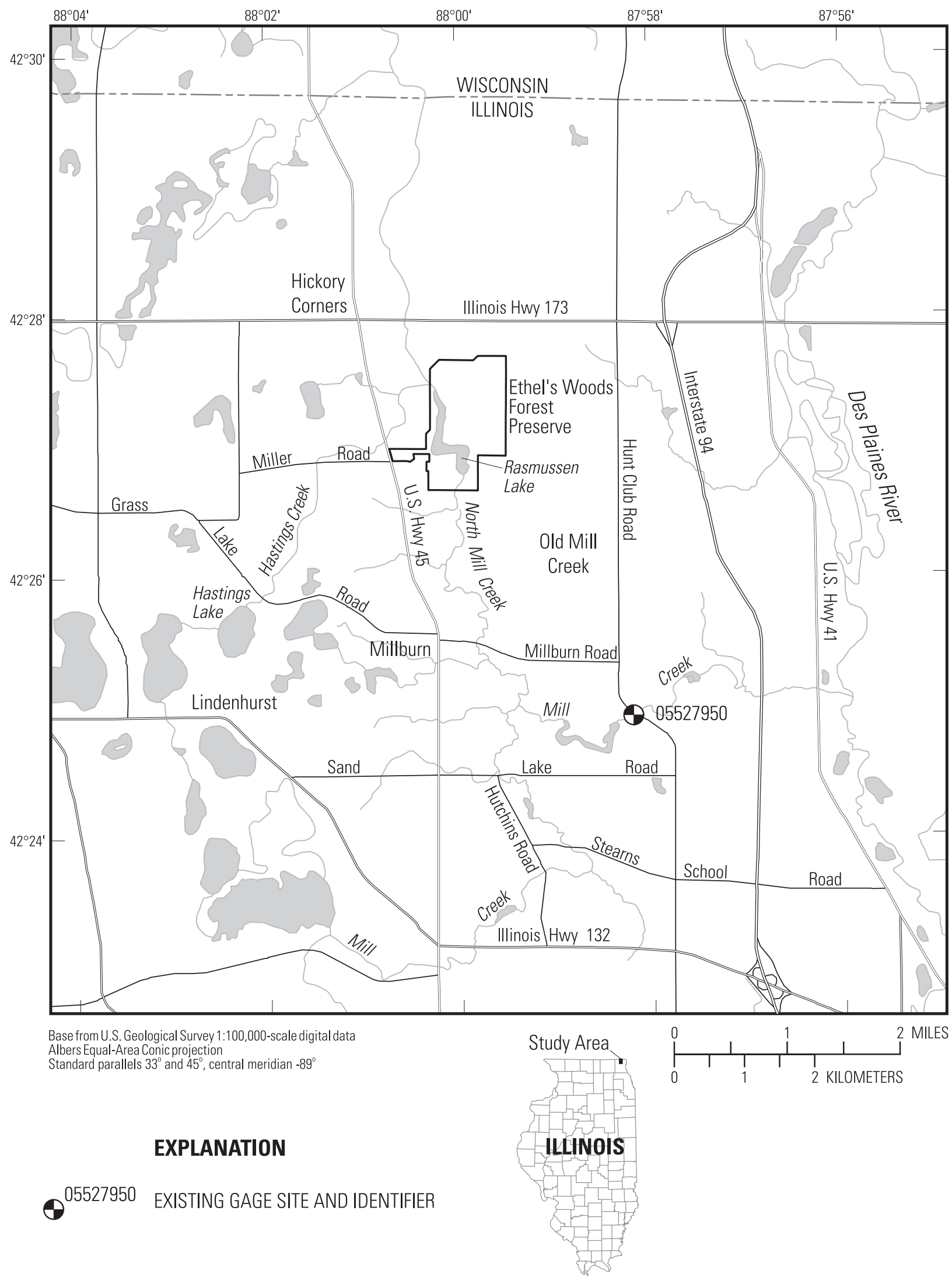

Figure 1. Location of Rasmussen Lake in Ethel's Woods Forest Preserve, near Old Mill Creek, Illinois. 


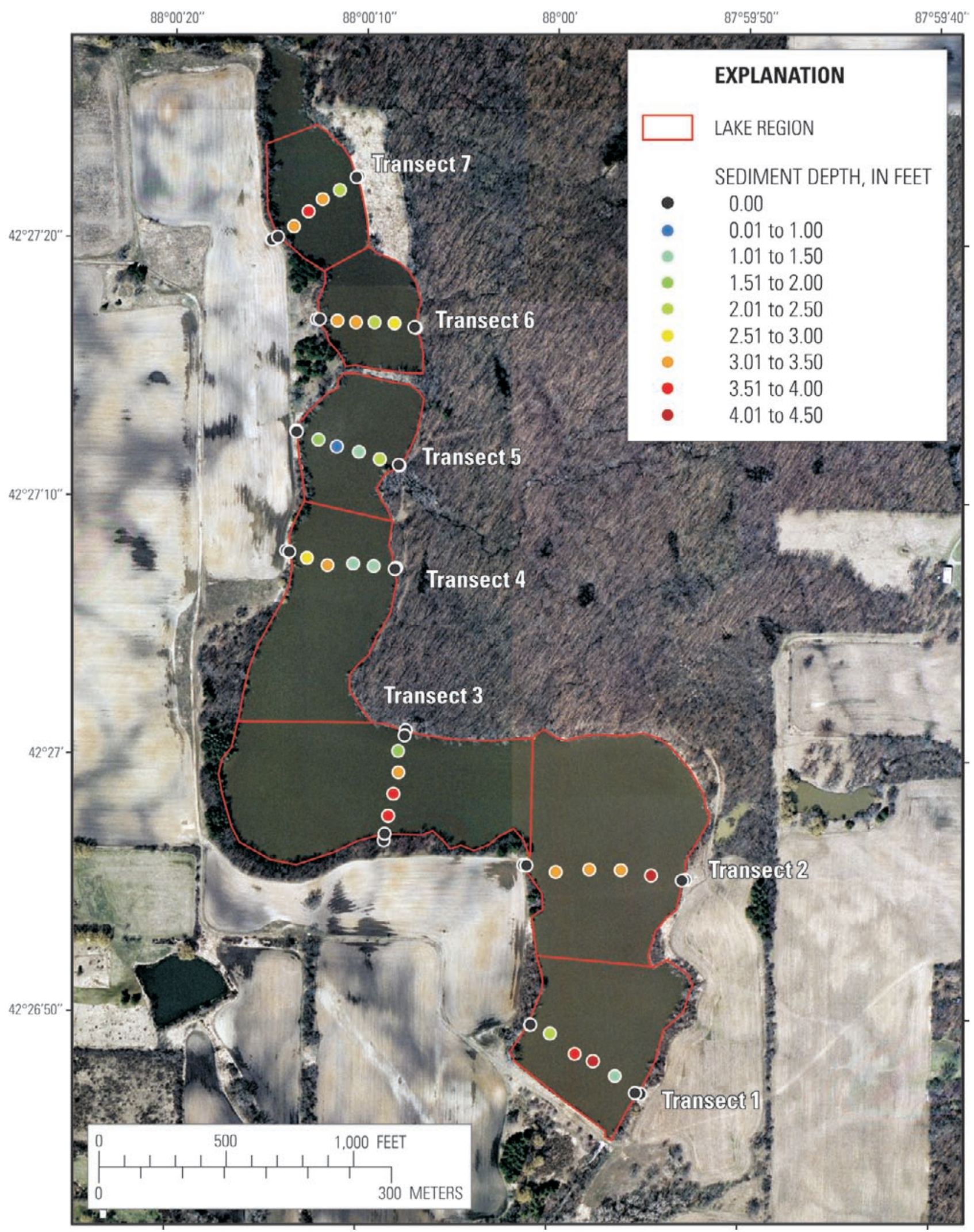

Figure 2. Sediment thicknesses and coring locations on Rasmussen Lake in Ethel's Woods Forest Preserve, near Old Mill Creek, Illinois. Lake regions are numbered by the transect number contained within the region. 
from the right edge of water (right defined looking in the downstream direction), and coordinates were determined with an accuracy of 9 to $20 \mathrm{ft}$ with a handheld Garmin V Global Positioning System (GPS) (appendix A).

The sediment thickness was determined to be the difference in elevation between the present-day top of the deposited sediment and the surface of the underlying hard or coarse material. The hard or coarse material is assumed to be at the elevation of pre-dam sediment surface (streambed, streambank, or flood plain). A line with a small weight attached to the end was used to determine the depth of water and surface of deposited sediment. A sediment probe was then used to determine the top of the hard material (bottom of the deposited sediment).

Coring tubes were driven into the bed to the point of refusal with repeated weighted blows. Cores were composed of either stiff clay or gravel in the lowest level of the core (predam sediment surface). Sampling equipment consisted of a 2in. diameter clear plastic liner tube (made of cellulose acetate butyrate) (fig. 3). The sleeve was contained in an Ogeechee weight-driven coring device.

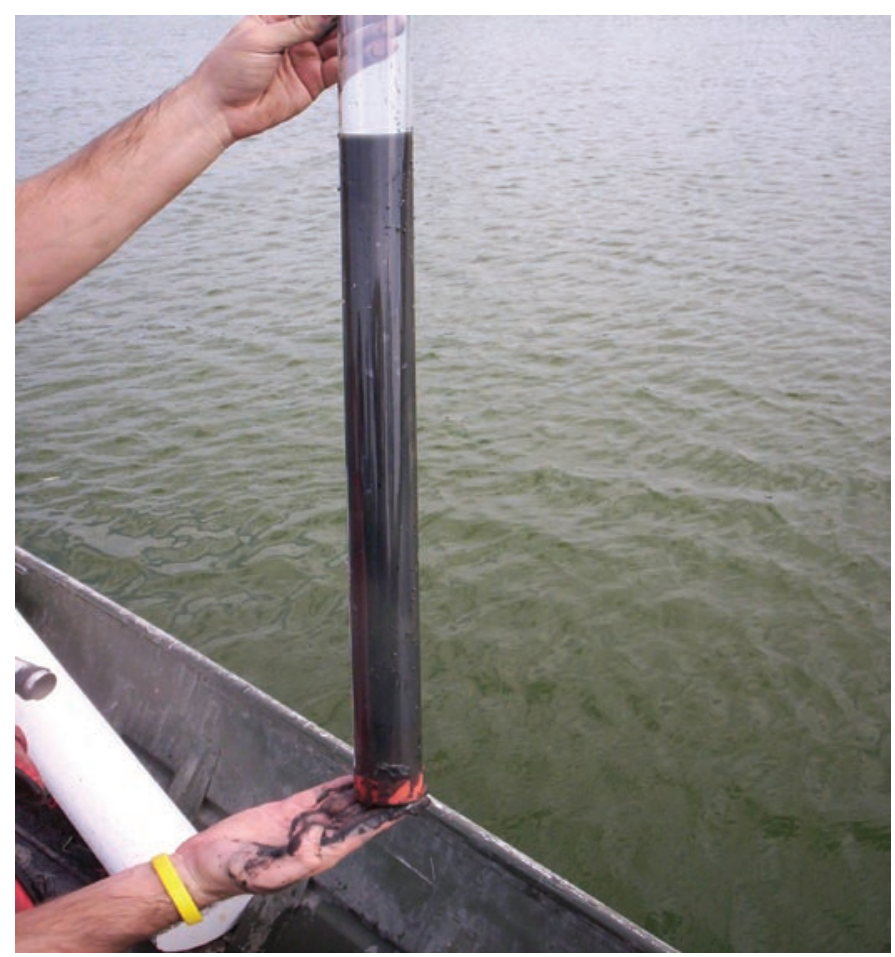

Figure 3. Lake sediment core in a clear plastic liner tube.

\section{Sedimentation Analysis}

The maximum sediment thickness was consistently 3.0$4.5 \mathrm{ft}$ thick from the dam to the upper end of the lake with the exception of thicknesses less than $2.5 \mathrm{ft}$ near the shore and in transect 5 (fig. 2, fig. 4, and appendix B). The old roadway on an earthen berm and small bridge (spanning approximately three-quarters of the lake) between transects 5 and 6 could be acting as a sediment trap during floods which would explain the low sediment thicknesses in transect 5. Sediment thickness did not increase either in the upstream or downstream direction. The average-transect sediment thicknesses ranged from $1.8 \mathrm{ft}$ to $2.7 \mathrm{ft}$ (fig. 4, table 1, and appendix B). The average-transect sediment thicknesses were multiplied by the lake surface area (for a representative lake region) to obtain an approximate sediment volume. Lake regions are numbered by the transect number contained within the region (fig. 2 and table 1). The approximate total sediment volume that has accumulated in the lake is 115.1 acre- $\mathrm{ft}$ (table 1 and appendix B) for the 51.4 acres analyzed.

Table 1. Surface area, average-transect sediment thickness, and sediment volumes of Rasmussen Lake in Ethel's Woods Forest Preserve, near Old Mill Creek, Illinois.

[---, not applicable $]$

\begin{tabular}{cccc}
\hline $\begin{array}{c}\text { Lake } \\
\text { region } \\
\text { (fig. 2) }\end{array}$ & $\begin{array}{c}\text { Lake surface } \\
\text { area } \\
\text { (acres) }\end{array}$ & $\begin{array}{c}\text { Average- } \\
\text { transect } \\
\text { sediment } \\
\text { thickness } \\
\text { (feet) }\end{array}$ & $\begin{array}{c}\text { Sediment } \\
\text { volume } \\
\text { (acre-feet) }\end{array}$ \\
\hline 1 & 7.0 & 1.9 & 13.6 \\
2 & 11.9 & 2.7 & 32.4 \\
3 & 12.5 & 2.5 & 31.0 \\
4 & 8.1 & 1.8 & 14.5 \\
5 & 4.5 & 1.2 & 5.4 \\
6 & 3.6 & 2.3 & 8.4 \\
7 & 3.8 & 2.5 & 9.8 \\
\hline Total & 51.4 & --- & 115.1 \\
\hline
\end{tabular}

In general, the sediment consisted of clays and silts throughout all the sediment cores (Enviro-Test/Perry Laboratories, Inc., written communication, 2005). Constrictions at old road crossings of the lake above the study area appear to have limited sediment transport; therefore, sediment deposition was primarily clays and silts. Only in the core sediments at the point of refusal were sands and gravels present. The uniform sediment deposition is consistent with fine materials slowing and settling out of the water column in most of the lake area sampled. The top of the cores were observed to be composed of flocculent materials. The flocculent materials at the top and the high percentage of fine material throughout caused the sediment core to compact during coring. Because the cores were compacted, they were not used to measure the thickness of the sediment deposition.

Given that the sediments are composed primarily of clays and silts, a gradual removal (over a period of a year or more) of the dam may be optimal. Once the dam was lowered, it is likely that a nickpoint (sometimes referred to as a headcut) 

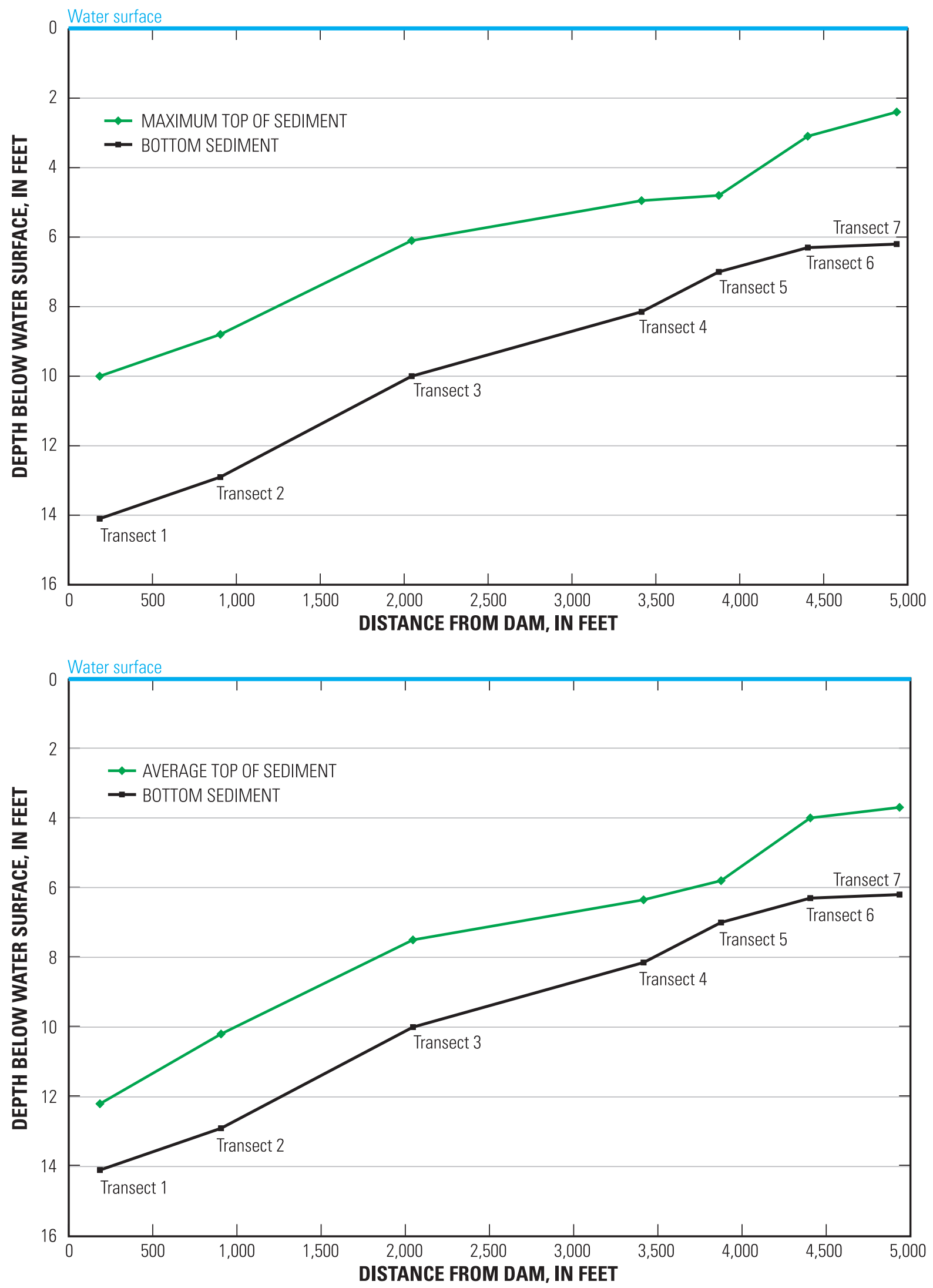

Figure 4. Maximum and average sediment thicknesses for each transect on Rasmussen Lake in Ethel's Woods Forest Preserve, near Old Mill Creek, Illinois. 


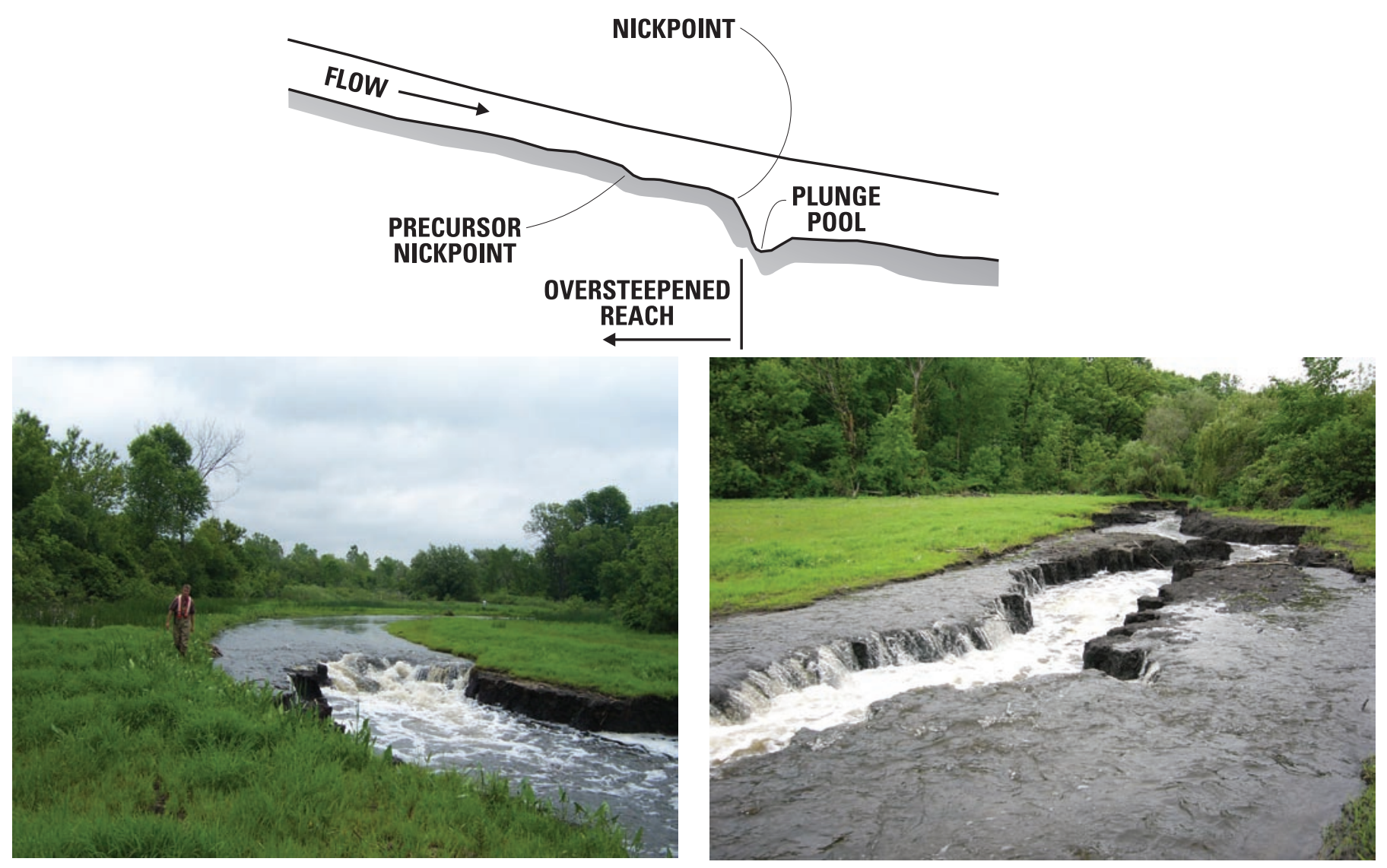

Figure 5. Diagram of a nickpoint (modified from Schumm and others, 1984) (top), and example of nickpoint progression after gradual removal of Brewster Creek dam near St. Charles, Illinois (bottom).

would develop and follow the old stream channel (fig. 5). A nickpoint is an oversteepened reach of a stream or old lake bed where erosion can occur if the eroding forces of the flow are greater than the resisting forces of bed material. The base level of the dam will determine size of the nickpoint. A more gradual drop in base level will allow a staged progression and size of nickpoint. The uniform sediment thicknesses could cause a uniform release of sediment as the nickpoint progresses through the old stream channel. Most of the sediment will be removed as the nickpoint progresses through the old stream channel unless a large flood occurs immediately after lowering the dam, during which more of the floodplain sediments could be removed. If the flood-plain sediments are allowed to dewater and vegetate, the stability of these sediments will increase and be less likely to erode. As portions of the lake are dewatered through gradual lowering of the dam, the sediments are allowed to consolidate and vegetate in stages. Given these effects of the gradual lowering, sediment yield per year would be less during and after lowering than if the entire dam were removed at one time.

Determining the location of the old stream channel is important because the nickpoint will most likely progress along that path. The old stream channel could not be determined at the sampling intervals used along the transects in this study. Sediment probes at a 2-ft interval along the 400-500 $\mathrm{ft}$ transect (or use of geophysical methods) would be required to determine stream channel location, depth, and width. The thickness of the sediment would be expected to increase in the old stream channel. Over the years, the sediment has filled in the lake area creating a relatively flat bottom. Because the old stream channel area would have been deeper than the surrounding ground surface, the thickness of the sediment in the old channel would be greater. Such differences in sediment thicknesses were not observed in the transects collected as part of this study.

\section{Potential Future Work}

A more detailed sediment thickness survey of the Rasmussen Lake would provide information valuable to any modification of the dam. Such a survey would involve more depth measurements with a sediment probe and additional cross sections of the stream channel and lake bottom. The establishment of survey monuments at cross sections would allow for repeated monitoring. During and after any modifications of the dam, subsequent surveys and suspended-sediment monitoring (inflow and outflow) will help develop criteria on sediment delivery and hydraulic conveyance for the modification of dams in Illinois. 


\section{Summary}

The Lake County Forest Preserve District (LCFPD) is investigating the possibility of modifying the dam on Rasmussen Lake in Ethel's Woods Forest Preserve, near Old Mill Creek, Illinois. In 2005, the U.S. Geological Survey-Illinois Water Science Center and the LCFPD began a cooperative study to collect sediment cores and investigate sedimentation in Rasmussen Lake. This information will be helpful to waterresource managers in analysis of dam-modification strategy throughout northeastern Illinois. Methods and analyses of this study can potentially be applied to similar watersheds in the Midwest with older impoundments.

Twenty-eight sediment sampling locations were identified along seven transects in Rasmussen Lake to determine sediment thickness and obtain sediment material for physical and chemical analyses. Four coring locations were selected at equal intervals on each of seven transects. The maximum sediment thickness was consistently 3.0-4.5 ft deep from the dam to the upper end of the lake, with the exception of sediment thickness less than $2.5 \mathrm{ft}$ near the shore and in transect 5. The old roadway on an earthen berm and small bridge (spanning approximately three-quarters of the lake) between transects 5 and 6 could be acting as a sediment trap during floods which would explain the low sediment thicknesses in transect 5. Overall, the sediment thickness in the lake bed did not exhibit a tendency to increase in the upstream or downstream direction.

The average-transect sediment thickness ranged from 1.8 $\mathrm{ft}$ to $2.7 \mathrm{ft}$. The average sediment thicknesses were multiplied by the lake surface area (for a representative lake region) to obtain an approximate sediment volume. The approximate total sediment volume that has accumulated in the lake is 115.1 acre-ft for the 51.4 acres analyzed.

Given that the sediments are composed primarily of clays and silts, a gradual removal (over a period of a year or more) of the dam may be optimal. A more gradual drop in base level will allow a staged progression and size of nickpoint. If the flood-plain sediments are allowed to dewater and vegetate, the stability of these sediments will increase and be less likely to erode. As portions of the lake are dewatered through gradual lowering of the dam, the sediments are allowed to consolidate and vegetate in stages. Using a gradual removal, sediment yield per year would be less during and after lowering than if the entire dam were removed at one time.

\section{Acknowledgments}

James Anderson and Jennifer Filipiak (of the Lake County Forest Preserve District) supported the sediment coring and sedimentation analysis. They also facilitated communications with other LCFPD staff to install boat ramps and survey control points for future detailed transect surveys. Technical assistance was also provided by the following
USGS-IWSC employees: Perry Draper (assisted with the measurement of sediment thickness and sediment coring); Jennifer Sharpe (report illustration development); and Angel Martin Jr. (report editing). Jennifer Filipiak and Perry Draper provided colleague technical reviews for report preparation.

\section{References Cited}

Colwell, M., Adam, M., Brant, C.L., Marencik, J., Pfister, M., 2002, 2001 Summary Report of Rasmussen Lake, Lake County, Illinois, Lake County Health Department Environmental Health Services Lake Management Unit, 14 p., accessed on June 2, 2006 at URL http://www.co.lake. il.us/health/pdfs/ehs/lakereports/Rasmussen.pdf

Lake County Forest Preserve, 2006, accessed on February 21, 2006, at URL http://www.lcfpd.org.

Schumm, S.A., Harvey, M.D., Watson, C.C., 1984, Incised Channels: Morphology Dynamics, and Control, Water Resources Publications, Colorado, 200 p. 


\section{Appendix A: Sample Locations on Rasmussen Lake in Ethel's Woods Forest Preserve near Old Mill Creek, Illinois.}


Table A1. Sampling locations on Rasmussen Lake in Ethel's Woods Forest Preserve near Old Mill Creek, Illinois.

[Horizontal coordinate information is referenced to the World Geodetic System, 1984 (WGS 84); ft, feet; LEW, Left Edge of Water; REW, Right Edge of Water]

\begin{tabular}{|c|c|c|c|}
\hline $\begin{array}{l}\text { Location and sample } \\
\text { (fig. 2) }\end{array}$ & $\begin{array}{c}\text { Latitude } \\
\text { (decimal degree) }\end{array}$ & $\begin{array}{c}\text { Longitude } \\
\text { (decimal degree) }\end{array}$ & $\begin{array}{l}\text { Detailed } \\
\text { location }\end{array}$ \\
\hline \multicolumn{4}{|c|}{ Transect 1} \\
\hline Left Fence Post & 42.44639142 & -87.99864133 & $15 \mathrm{ft}$ from LEW \\
\hline Left Edge of Water & 42.44640274 & -87.99871970 & LEW \\
\hline Right Fence Post & 42.44712124 & -88.00024940 & $10 \mathrm{ft}$ REW \\
\hline Right Edge of Water & 42.44712442 & -88.00024722 & REW \\
\hline Sample 25 & 42.44703339 & -87.99996332 & $100 \mathrm{ft}$ from REW \\
\hline Sample 26 & 42.44681488 & -87.99959754 & $200 \mathrm{ft}$ from REW \\
\hline Sample 27 & 42.44674095 & -87.99933610 & $300 \mathrm{ft}$ from REW \\
\hline \multicolumn{3}{|c|}{ Transect 2} & $400 \mathrm{ft}$ from REW \\
\hline Left Fence Post & 42.44869854 & -87.99802249 & $10 \mathrm{ft}$ from LEW \\
\hline Left Edge of Water & 42.44869167 & -87.99807262 & LEW \\
\hline Right Fence Post & 42.44883860 & -88.00037814 & $13 \mathrm{ft}$ from REW \\
\hline Right Edge of Water & 42.44883584 & -88.00033296 & REW \\
\hline Sample 24 & 42.44874456 & -87.99851770 & $500 \mathrm{ft}$ from REW \\
\hline Sample 23 & 42.44879426 & -87.99895976 & $375 \mathrm{ft}$ from REW \\
\hline Sample 22 & 42.44879678 & -87.99941892 & $250 \mathrm{ft}$ from REW \\
\hline Sample 21 & \multicolumn{2}{|l|}{ Transect 3} & $125 \mathrm{ft}$ from REW \\
\hline Left Fence Post & 42.45027811 & -88.00210783 & $4 \mathrm{ft}$ from LEW \\
\hline Left Edge of Water & 42.45022019 & -88.00212812 & LEW \\
\hline Right Fence Post & 42.44908834 & -88.00241067 & $8 \mathrm{ft}$ from REW \\
\hline Right Edge of Water & 42.44915773 & -88.00239721 & REW \\
\hline Sample 20 & 42.45005314 & -88.00221764 & $340 \mathrm{ft}$ from REW \\
\hline Sample 19 & 42.44982172 & -88.00220984 & $255 \mathrm{ft}$ from REW \\
\hline Sample 18 & 42.44959038 & -88.00228310 & $170 \mathrm{ft}$ from REW \\
\hline Sample 17 & \multicolumn{2}{|l|}{ Transect 4} & $85 \mathrm{ft}$ from REW \\
\hline Left Fence Post & 42.45202415 & -88.00228134 & $5 \mathrm{ft}$ from LEW \\
\hline Left Edge of Water & 42.45201317 & -88.00229693 & LEW \\
\hline Right Fence Post & 42.45219673 & -88.00388136 & $15 \mathrm{ft}$ from REW \\
\hline Right Edge of Water & 42.45218416 & -88.00383492 & REW \\
\hline Sample 13 & 42.45211836 & -88.00357735 & $85 \mathrm{ft}$ from REW \\
\hline Sample 14 & 42.45204234 & -88.00327719 & $170 \mathrm{ft}$ from REW \\
\hline Sample 15 & 42.45206296 & -88.00290478 & $255 \mathrm{ft}$ from REW \\
\hline Sample 16 & \multicolumn{2}{|l|}{ Transect 5} & $340 \mathrm{ft}$ from REW \\
\hline Left Fence Post & 42.45312477 & -88.00224488 & $7 \mathrm{ft}$ from LEW \\
\hline Left Edge of Water & 42.45313249 & -88.00225519 & LEW \\
\hline Right Fence Post & 42.45349098 & -88.00375446 & $12 \mathrm{ft} \mathrm{REW}$ \\
\hline Right Edge of Water & 42.45347589 & -88.00374926 & REW \\
\hline Sample 9 & 42.45339409 & -88.00342957 & $85 \mathrm{ft}$ from REW \\
\hline Sample 10 & 42.45332225 & -88.00316194 & $170 \mathrm{ft}$ from REW \\
\hline Sample 11 & 42.45326442 & -88.00283790 & $255 \mathrm{ft}$ from REW \\
\hline Sample 12 & \multicolumn{2}{|l|}{ Transect 6} & $340 \mathrm{ft}$ from REW \\
\hline Left Fence Post & 42.45460879 & -88.00203625 & $7 \mathrm{ft}$ from LEW \\
\hline Left Edge of Water & 42.45461474 & -88.00205193 & LEW \\
\hline Right Fence Post & 42.45468901 & -88.00347316 & $12 \mathrm{ft}$ from REW \\
\hline Right Edge of Water & 42.45468691 & -88.00343041 & REW \\
\hline Sample 5 & 42.45467409 & -88.00317225 & $75 \mathrm{ft}$ from REW \\
\hline Sample 6 & 42.45465975 & -88.00290269 & $150 \mathrm{ft}$ from REW \\
\hline Sample 7 & 42.45466378 & -88.00263514 & $225 \mathrm{ft}$ from REW \\
\hline Sample 8 & \multicolumn{2}{|l|}{ Transect 7} & $300 \mathrm{ft}$ from REW \\
\hline Left Fence Post & 42.45623262 & -88.00288894 & $8 \mathrm{ft}$ from LEW \\
\hline Left Edge of Water & 42.45622138 & -88.00291920 & LEW \\
\hline Right Fence Post & 42.45554295 & -88.00413315 & $23 \mathrm{ft}$ from REW \\
\hline Right Edge of Water & 42.45557221 & -88.00404891 & REW \\
\hline Sample 1 & 42.45568737 & -88.00381933 & $75 \mathrm{ft}$ from REW \\
\hline Sample 2 & 42.45584772 & -88.00361079 & $150 \mathrm{ft}$ from REW \\
\hline Sample 3 & 42.45598200 & -88.00340753 & $225 \mathrm{ft}$ from REW \\
\hline Sample 4 & 42.45608099 & -88.00316052 & $300 \mathrm{ft}$ from REW \\
\hline
\end{tabular}




\section{Appendix B: Sediment Summary for Transects on Rasmussen Lake in Ethel's Woods Forest Preserve near Old Mill Creek, Illinois.}

Abbreviations used in appendix:

LEW - Left Edge of Water (defined looking in the downstream direction)

REW - Right Edge of Water (defined looking in the downstream direction)

$\mathrm{ft}-$ feet

$\mathrm{ft}^{2}-$ square feet

\section{Transect 1}

\begin{tabular}{|c|c|c|c|c|c|}
\hline \multirow{2}{*}{$\begin{array}{l}\text { Sample } \\
\text { number }\end{array}$} & \multirow{2}{*}{$\begin{array}{c}\text { Distance from } \\
\text { REW (ft) } \\
\end{array}$} & \multicolumn{2}{|c|}{ Sediment depths ${ }^{1}$ (ft) } & \multirow{2}{*}{$\begin{array}{c}\text { Sediment } \\
\text { thickness (ft) }\end{array}$} & \multirow{2}{*}{$\begin{array}{l}\text { Sediment } \\
\text { area }\left(f t^{2}\right)\end{array}$} \\
\hline & & Top & Bottom & & \\
\hline REW & 0 & 0 & 0 & 0 & 0 \\
\hline 25 & 100 & 11.1 & 9.2 & 2.1 & 105 \\
\hline 26 & 200 & 10.0 & 13.9 & 3.9 & 300 \\
\hline 27 & 300 & 10.0 & 14.1 & 4.1 & 400 \\
\hline 28 & 400 & 9.2 & 10.4 & 1.2 & 265 \\
\hline LEW & 620 & 0 & 0 & 0 & 132 \\
\hline
\end{tabular}

${ }^{1}$ Sediment depths taken from water surface.

Representative Surface Area and Distances:

Lake Surface Area $($ LSA) =

7.0 acres

Upstream Distance (UD) $=$

$360 \mathrm{ft}$

Downstream Distance $(\mathrm{DD})=$

$185 \mathrm{ft}$

Cross-Section Top Width $(\mathrm{TW})=$

$620 \mathrm{ft}$

Sedimentation Summary:

Total Sediment Area $(\mathrm{SA})=$

$1,202 \mathrm{ft}^{2}$

Average Sediment Thickness $(\mathrm{ST}=\mathrm{SA} / \mathrm{TW})=$

$1.9 \mathrm{ft}$

Sediment Volume $(\mathrm{SV}=\mathrm{ST} * \mathrm{LSA})=$

13.6 acre-ft 


\section{Transect 2}

\begin{tabular}{|c|c|c|c|c|c|}
\hline \multirow{2}{*}{$\begin{array}{l}\text { Sample } \\
\text { number }\end{array}$} & \multirow{2}{*}{$\begin{array}{c}\text { Distance from } \\
\text { REW (ft) } \\
\end{array}$} & \multicolumn{2}{|c|}{ Sediment depths' $(\mathrm{ft})$} & \multirow{2}{*}{$\begin{array}{c}\text { Sediment } \\
\text { thickness (ft) }\end{array}$} & \multirow{2}{*}{$\begin{array}{c}\text { Sediment } \\
\text { area }\left(\mathrm{ft}^{2}\right)\end{array}$} \\
\hline & & Top & Bottom & & \\
\hline REW & 0 & 0 & 0 & 0 & 0 \\
\hline 21 & 125 & 8.1 & 11.2 & 3.1 & 194 \\
\hline 22 & 250 & 8.1 & 11.4 & 3.3 & 400 \\
\hline 23 & 375 & 8.2 & 11.3 & 3.1 & 400 \\
\hline 24 & 500 & 8.8 & 12.9 & 4.1 & 450 \\
\hline LEW & 620 & 0 & 0 & 0 & 246 \\
\hline
\end{tabular}

${ }^{1}$ Sediment depths taken from water surface.

\section{Representative Surface Area and Distances:}

Lake Surface Area (LSA) =

Upstream Distance (UD) $=$

Downstream Distance $(\mathrm{DD})=$

Cross-Section Top Width $(\mathrm{TW})=$
11.9 acres

$570 \mathrm{ft}$

$360 \mathrm{ft}$

$620 \mathrm{ft}$

\section{Sedimentation Summary:}

Total Sediment Area $(\mathrm{SA})=$

$1,690 \mathrm{ft}^{2}$

Average Sediment Thickness $(\mathrm{ST}=\mathrm{SA} / \mathrm{TW})=$

$2.7 \mathrm{ft}$

Sediment Volume $(\mathrm{SV}=\mathrm{ST} * \mathrm{LSA})=$

32.4 acre-ft

\section{Transect 3}

\begin{tabular}{|c|c|c|c|c|c|}
\hline \multirow{2}{*}{$\begin{array}{l}\text { Sample } \\
\text { number }\end{array}$} & \multirow{2}{*}{$\begin{array}{c}\text { Distance from } \\
\text { REW (ft) }\end{array}$} & \multicolumn{2}{|c|}{ Sediment Depths ${ }^{1}$ (ft) } & \multirow{2}{*}{$\begin{array}{c}\text { Sediment } \\
\text { thickness (ft) }\end{array}$} & \multirow{2}{*}{$\begin{array}{l}\text { Sediment } \\
\text { area }\left(\mathrm{ft}^{2}\right)\end{array}$} \\
\hline & & Top & Bottom & & \\
\hline REW & 0 & 0 & 0 & 0 & 0 \\
\hline 17 & 85 & 6.1 & 10.0 & 3.9 & 166 \\
\hline 18 & 170 & 6.1 & 9.7 & 3.6 & 319 \\
\hline 19 & 255 & 5.9 & 8.4 & 3.5 & 302 \\
\hline 20 & 340 & 5.9 & 7.5 & 1.6 & 217 \\
\hline LEW & 435 & 0 & 0 & 0 & 76 \\
\hline
\end{tabular}

${ }^{1}$ Sediment depths taken from water surface.

\section{Representative Surface Area and Distances:}

Lake Surface Area $($ LSA $)=$

Upstream Distance (UD) =

Downstream Distance $(\mathrm{DD})=$

Cross-Section Top Width $(\mathrm{TW})=$

\section{Sedimentation Summary:}

Total Sediment Area $(\mathrm{SA})=$

Average Sediment Thickness $(\mathrm{ST}=\mathrm{SA} / \mathrm{TW})=$

Sediment Volume $(\mathrm{SV}=\mathrm{ST} * \mathrm{LSA})=$

\author{
12.5 acres \\ $685 \mathrm{ft}$ \\ $570 \mathrm{ft}$ \\ $435 \mathrm{ft}$
}

$1,079 \mathrm{ft}^{2}$

$2.5 \mathrm{ft}$

31.0 acre-ft 


\section{Transect 4}

\begin{tabular}{|c|c|c|c|c|c|}
\hline \multirow{2}{*}{$\begin{array}{l}\text { Sample } \\
\text { number }\end{array}$} & \multirow{2}{*}{$\begin{array}{c}\text { Distance from } \\
\text { REW (ft) }\end{array}$} & \multicolumn{2}{|c|}{ Sediment depths ${ }^{1}$ (ft) } & \multirow{2}{*}{$\begin{array}{c}\text { Sediment } \\
\text { thickness (ft) }\end{array}$} & \multirow{2}{*}{$\begin{array}{l}\text { Sediment } \\
\text { area }\left(\mathrm{ft}^{2}\right)\end{array}$} \\
\hline & & Top & Bottom & & \\
\hline REW & 0 & 0 & 0 & 0 & 0 \\
\hline 13 & 85 & 5.0 & 8.2 & 3.2 & 136 \\
\hline 14 & 170 & 4.9 & 8.1 & 3.2 & 272 \\
\hline 15 & 255 & 4.7 & 5.8 & 1.1 & 183 \\
\hline 16 & 340 & 4.8 & 6.3 & 1.5 & 111 \\
\hline LEW & 430 & 0 & 0 & 0 & 68 \\
\hline
\end{tabular}

${ }^{1}$ Sediment depths taken from water surface.

\section{Representative Surface Area and Distances:}

Lake Surface Area $($ LSA) $=$

Upstream Distance $(\mathrm{UD})=$

Downstream Distance $(\mathrm{DD})=$

Cross-Section Top Width $(\mathrm{TW})=$

\section{Sedimentation Summary:}

Total Sediment Area $(\mathrm{SA})=$ Average Sediment Thickness $(\mathrm{ST}=\mathrm{SA} / \mathrm{TW})=$ Sediment Volume $(\mathrm{SV}=\mathrm{ST} * \mathrm{LSA})=$

\author{
8.1 acres \\ $230 \mathrm{ft}$ \\ $685 \mathrm{ft}$ \\ $430 \mathrm{ft}$
}

$769 \mathrm{ft}^{2}$

$1.8 \mathrm{ft}$

14.5 acre-ft

\section{Transect 5}

\begin{tabular}{|c|c|c|c|c|c|}
\hline \multirow{2}{*}{$\begin{array}{l}\text { Sample } \\
\text { number }\end{array}$} & \multirow{2}{*}{$\begin{array}{c}\text { Distance from } \\
\text { REW (ft) } \\
\end{array}$} & \multicolumn{2}{|c|}{ Sediment depths' (ft) } & \multirow{2}{*}{$\begin{array}{c}\text { Sediment } \\
\text { thickness (ft) }\end{array}$} & \multirow{2}{*}{$\begin{array}{l}\text { Sediment } \\
\text { area }\left(\mathrm{ft}^{2}\right)\end{array}$} \\
\hline & & Top & Bottom & & \\
\hline REW & 0 & 0 & 0 & 0 & 0 \\
\hline 9 & 85 & 4.5 & 6.1 & 1.6 & 68 \\
\hline 10 & 170 & 5.3 & 6.0 & 0.7 & 98 \\
\hline 11 & 255 & 5.5 & 6.9 & 1.4 & 89 \\
\hline 12 & 340 & 4.8 & 7.0 & 2.2 & 153 \\
\hline LEW & 428 & 0 & 0 & 0 & 97 \\
\hline
\end{tabular}

${ }^{1}$ Sediment depths taken from water surface.

\section{Representative Surface Area and Distances:}

Lake Surface Area $($ LSA $)=$

Upstream Distance $($ UD) $=$

Downstream Distance $(\mathrm{DD})=$

Cross-Section Top Width $(\mathrm{TW})=$

\section{Sedimentation Summary:}

Total Sediment Area $(\mathrm{SA})=$

Average Sediment Thickness $(\mathrm{ST}=\mathrm{SA} / \mathrm{TW})=$

Sediment Volume $(\mathrm{SV}=\mathrm{ST} * \mathrm{LSA})=$

\author{
4.5 acres \\ $265 \mathrm{ft}$ \\ $230 \mathrm{ft}$ \\ $428 \mathrm{ft}$
}

$505 \mathrm{ft}^{2}$

$1.2 \mathrm{ft}$

5.4 acre-ft 
Transect 6

\begin{tabular}{|c|c|c|c|c|c|}
\hline \multirow{2}{*}{$\begin{array}{l}\text { Sample } \\
\text { number }\end{array}$} & \multirow{2}{*}{$\begin{array}{c}\text { Distance from } \\
\text { REW (ft) }\end{array}$} & \multicolumn{2}{|c|}{ Sediment depths' ${ }^{1}(\mathrm{ft})$} & \multirow{2}{*}{$\begin{array}{c}\text { Sediment } \\
\text { thickness (ft) }\end{array}$} & \multirow{2}{*}{$\begin{array}{l}\text { Sediment } \\
\text { area }\left(\mathrm{ft}^{2}\right)\end{array}$} \\
\hline & & Top & Bottom & & \\
\hline REW & 0 & 0 & 0 & 0 & 0 \\
\hline 5 & 75 & 3.0 & 6.2 & 3.2 & 120 \\
\hline 6 & 150 & 3.2 & 6.4 & 3.2 & 240 \\
\hline 7 & 225 & 3.2 & 5.6 & 2.4 & 210 \\
\hline 8 & 300 & 3.3 & 6.3 & 3.0 & 203 \\
\hline LEW & 380 & 0 & 0 & 0 & 120 \\
\hline
\end{tabular}

${ }^{1}$ Sediment depths taken from water surface.

Representative Surface Area and Distances:

Lake Surface Area $($ LSA) $=$

Upstream Distance (UD) $=$

Downstream Distance $(\mathrm{DD})=$

Cross-Section Top Width $(\mathrm{TW})=$

\section{Sedimentation Summary:}

Total Sediment Area $(\mathrm{SA})=$

Average Sediment Thickness $(\mathrm{ST}=\mathrm{SA} / \mathrm{TW})=$

Sediment Volume $(\mathrm{SV}=\mathrm{ST} * \mathrm{LSA})=$
3.6 acres

$265 \mathrm{ft}$

$265 \mathrm{ft}$

$380 \mathrm{ft}$

$893 \mathrm{ft}^{2}$

$2.3 \mathrm{ft}$

8.4 acre-ft

\section{Transect 7}

\begin{tabular}{|c|c|c|c|c|c|}
\hline \multirow{2}{*}{$\begin{array}{l}\text { Sample } \\
\text { number }\end{array}$} & \multirow{2}{*}{$\begin{array}{c}\text { Distance from } \\
\text { REW (ft) } \\
\end{array}$} & \multicolumn{2}{|c|}{ Sediment depths ${ }^{1}(\mathrm{ft})$} & \multirow{2}{*}{$\begin{array}{c}\text { Sediment } \\
\text { thickness (ft) }\end{array}$} & \multirow{2}{*}{$\begin{array}{l}\text { Sediment } \\
\text { Area }\left(f^{2}\right)\end{array}$} \\
\hline & & Top & Bottom & & \\
\hline REW & 0 & 0 & 0 & 0 & 0 \\
\hline 1 & 75 & 2.5 & 5.7 & 3.2 & 120 \\
\hline 2 & 150 & 2.4 & 6.2 & 3.8 & 263 \\
\hline 3 & 225 & 2.5 & 5.8 & 3.3 & 266 \\
\hline 4 & 300 & 2.7 & 5.2 & 2.5 & 218 \\
\hline LEW & 380 & 0 & 0 & 0 & 100 \\
\hline
\end{tabular}

${ }^{1}$ Sediment depths taken from water surface.

\section{Representative Surface Area and Distances:}

Lake Surface Area $($ LSA $)=$

Upstream Distance (UD) =

Downstream Distance $(\mathrm{DD})=$

Cross-Section Top Width $($ TW $)=$

\section{Sedimentation Summary:}

Total Sediment Area $(\mathrm{SA})=$

Average Sediment Thickness $(\mathrm{ST}=\mathrm{SA} / \mathrm{TW})=$

Sediment Volume $(\mathrm{SV}=\mathrm{ST} * \mathrm{LSA})=$

\author{
3.8 acres \\ $290 \mathrm{ft}$ \\ $265 \mathrm{ft}$ \\ $380 \mathrm{ft}$
}

$966 \mathrm{ft}^{2}$

$2.5 \mathrm{ft}$

9.8 acre-ft 


\section{$\frac{1}{4}$}

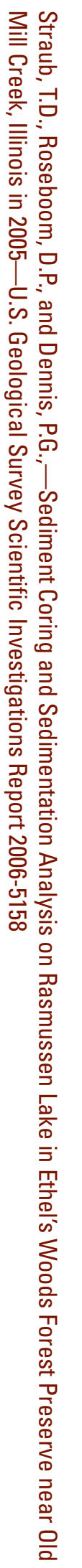

8 Printed on recycled paper 